\title{
Carta a Marta Rossetti
}

Ana Paula Felicíssimo de Camargo Lima ${ }^{1}$

Querida Marta,

São Paulo, 14 de agosto de 2007.

Passei a tarde assistindo a uma palestra de história da arte na FAU-Maranhão e me lembrei muito de você, de quando você me contava de suas aventuras nos anos de sua graduação em Arquitetura, e do início de sua pesquisa sobre Anita Malfatti com a orientação do professor Flávio Motta. Aliás, junto disto, muitas outras recordações boas vieram... Como já lhe disse, mais de uma vez: aprendi muito contigo, que confiou em mim desde a época do estágio sob sua supervisão, lá nos idos de 1992, e que me mostrou o quão importante era o contato com as fontes primárias... E você sabe também, por acompanhar de perto, desde o início, meu trabalho no IEB, o quanto eu peguei gosto pelas inquietações que aparecem nesse encontro direto com as obras e documentos originais. Hoje, quando pesquiso, a cada nova descoberta que faço, você, de algum modo, está sempre comigo.

Você já deve saber também que o pessoal do IEB está organizando, por estes dias, uma bonita homenagem para você. Uma homenagem que você bem merece, depois de todos estes anos dedicados ao trabalho. Nesta homenagem vão remontar a exposição que curamos juntas, Anita Malfatti gravadora: uma recuperação. Remontagem que me faz lembrar ainda mais de você e me emocionar, pensando na falta que você faz por aqui... Sabe, Marta, acredito que essa mostra - que foi fruto de um trabalho que você acompanhou desde quando eu recebi, em 1996, a bolsa da VITAE, para a recuperação da obra gráfica da Anita - foi também a celebração de nossa amizade, e do companheirismo e carinho presentes em nosso convívio quase diário nestes últimos 15 anos. A edição póstuma das gravuras da Anita, que conseguimos realizar, foi de certo modo a materialização de uma busca marcada pela persistência e a paciência - qualidades que também aprendi com você. Estas matrizes calcográficas, agora impressas, permitindo novos olhares sobre a obra de Anita, são como sementes que voltam a frutificar após um longo inverno.

1 Coleção de Artes do IEB. 
Agora mesmo, enquanto escrevo, vou me lembrando ainda das visitas que fizemos à família Malfatti - que tanto a admira e confia em você - e de outros momentos, como nossas aventuras pelo Rio de Janeiro em 1996, durante a retrospectiva da Anita, e, mais recentemente, de como você e o Luiz Olavo me receberam em Paris, tão carinhosamente... Ah Marta! Sinto muito sua falta!... Sinto saudade de nossas reuniões e de nossas risadas. E havendo ainda tanta coisa que quero compartilhar com você, e tanta lembrança boa, penso na própria Anita, que escreveu: "felizmente o tempo não conta por hoje."

Com muito afeto, Ana Paula 